THURSDAY, APRIL 28, 1870.

\section{WHAT IS ENERGY?}

$T^{T}$ is only of late years that the laws of motion have been fully comprehended. No doubt it has been known since the time of Newton that there can be no action without reaction; or, in other words, if we define momentum to be the product of the mass of a moving body into its velocity of motion, then whenever this is generated in one direction an equal amount is simultaneously generated in the opposite direction, and whenever it is destroyed in one direction an equal amount is simultaneously destroyed in the opposite direction. Thus the recoil of a gun is the appropriate reaction to the forward motion of the bullet, and the ascent of a rocket to the downrush of heated gas from its orifice; and in other cases where the action of the principle is not so apparent, its truth has notwithstanding been universally admitted.

It has, for instance, been perfectly well understood for the last 200 years that if a rock be detached from the top of a precipice 144 feet high it will reach the earth with the velocity of 96 feet in a second, while the earth will in return move up to meet it, if not with the same velocity yet with the same momentum. But inasmuch as the mass of the earth is very great compared with that of the rock, so the velocity of the former must be very small compared with that of the latter, in order that the momentum or product of mass into velocity may be the same for both. In fact, in this case, the velocity of the earth is quite insensible and may be disregarded.

The old conception of the laws of motion was thus sufficient to represent what takes place when the rock is in the act of traversing the air to meet the earth; but, on the other hand, the true physical concomitants of the crash which takes place when the two bodies have come together were entirely ignored. They met, their momentum was cancelled-that was enough for the old hypothesis.

So, when a hammer descends upon an anvil, it was considered enough to believe that the blow was stopped by the anvil; or when a break was applied to a carriage-wheel it was enough to imagine that the momentum of the carriage was stopped by friction. We shall presently allude to the names of those distinguished men who have come prominently forward as the champions of a juster conception of things, but in the meantime let us consider some of those influences which served to prepare men's minds for the reception of a truer hypothesis.

We live in a world of work, of work from which we cannot possibly escape; and those of us who do not require to work in order to eat, must yet in some sense perform work in order to live. Gradually, and by very slow steps, the true nature of work came to be understood. It was seen, for instance, that it involved a much less expenditure of energy for a man to carry a pound weight along a level road than to carry it an equal distance up to the top of a mountain.

It is not improbable that considerations of this kind may have led the way to a numerical estimate of work.

Thus, if we raise a pound weight one foot high against the force of gravity we may call it one unit of work, in which case two pounds raised one foot high or one pound raised two feet high would represent two units, and so on. We have therefore only to multiply the number of pounds by the vertical height in feet to which they are raised, and the product will represent the work done against gravity. The force of gravity being very nearly constant at the earth's surface, and always in action, is a very convenient force for this purpose; but any other force, such as that of a spring, would do equally well to measure work by. Generalising, we may say, the space moved over against a force multiplied into the intensity of that force will represent the quantity of work done. So much for the definition of work, and it is necessary to know what work is before proceeding to define Energy.

Now what does the word Energy really mean? In the first place it does not mean force.

Two substances may have an intense mutual attraction, in virtue of which they form a very intimate union with one another; but when once this union has been consummated, although the force still continues to exist, the combination is singularly deficient in Energy. Nor does Energy mean motion, for although we cannot have motion without Energy, yet we may have Energy without motion.

By the word Energy is meant the power of doing work; and the energy which a labouring man possesses means, in the strictly physical sense, the number of units of work which he is capable of accomplishing.

This is a subject which at this stage we may attempt to illustrate by reference to a very different department of knowledge.*

The analogy which we shall venture to institute is between the social and the physical world, in the hope that those who are more familiar with the former than with the latter may be led to perceive clearly what is meant by the word Energy in a strictly physical sense. Energy in the social world is well understood. When a man pur sues his course, undaunted by opposition and unappalled by obstacles, he is said to be a very energetic man.

By his energy is meant the power which he possesses of overcoming obstacles; and the amount of this energy is measured (in the loose way in which we measure such things) by the amount of obstacles which he can overcome-the amount of work which he can do. Such a man may in truth be regarded as a social cannon-ball. By means of his energy of character he will scatter the ranks of his opponents and demolish their ramparts. Nevertheless, a man of this kind will sometimes be defeated by an opponent who does not possess a tithe of his personal energy. Now, why is this? A reply to this question will, if we do not mistake, exhibit in a striking manner the likeness that exists between the social and the physical world. The reason is that, although his opponent may be deficient in personal energy, yet he may possess more than an equivalent in the high position which he occupies, and it is simply this position that enables him to combat successfully with a man of much greater personal energy than himself. If two men throw stones at one another, one of whom stands at the top of a house and the other at the bottom, the man at the top of the house has evidently the advantage.

So, in like manner, if two men of equal personal energy contend together, the one who has the highest social

* The subject has previously been discussed from this point of view by Messrs. Stewart and Lockyer in an article in Macmillan's Magazine, August $\times 868$. 
position has the best chance of succeeding. For this high position means energy under another form. It means that at some remote period a vast amount of personal energy was expended in raising the family into this high position. The founder of the family had, doubtless, greater energy than most of his fellows, and spent it in raising himself and his family into a position of advantage. The personal element may have long since disappeared from the family, but not before it had been transmuted into something else, in virtue of which the present representative is able to accomplish a great deal, owing solely to the high position which he has acquired through the efforts of another. We thus see that in the social tvorld we have what may justly be termed two kinds of energy, namely :-

1. Aatual or personal energy.

2. Energy derived from position.

Let us now again turn to the physical world. In this, as in the social world, it is difficult to ascend. The force of gravity may be compared to that force which keeps a man down in the world. If a stone be shot upwards with great velocity, it may be said to have in it a great deal of actual energy, because it has the power of doing useful work or of overcoming up to a great height the obstacle interposed by gravity to its ascent, just as a man of great energy has the power of overcoming obstacles. But this stone as it continues to mount upwards will do so with a gradually decreasing velocity, until at the summit of its flight all the actual energy with which it started will have been spent in raising it against the force of gravity to this elevated position. It is now moving with no velocity-just, in fact, beginning to turn-and we may suppose it to be caught and lodged upon the top of a house. Here, then, it remains at rest, without the slightest tendency to motion of any kind, and we are led to ask what has become of the energy with which it began its flight? Has this energy disappeared from the universe without leaving behind it any equivalent? Is it lost for ever, and utterly wasted? But the answer to this question must be reserved for another article.

BALFOUR STEWART

\section{LEGISLATION AND NATURE}

THE HE effect of Legislation upon Nature is one of those far-reaching subjects which men are only just beginning to investigate in a practical spirit. It is, of course, only a minor branch of the larger question of man's influence upon all external life and forms, but it has its special attractions, nevertheless, and may be pursued to advantage as an independent study. Incidentally, it illustrates many other problems. The diminutiveness of the Hindu cow, for example, may be due as much to the legislation which has made the domesticated animal sacred as to the nature of the climate of Hindustan. It is quite possible the oxen of this country would not have exhibited such a variety of forms and sizes had we selected one species and made it sacred some two or three thousand years ago. Take, again, the subject of maritime canals, which is now in its infancy. The Suez Canal has not existed long enough to have had any appreciable effect, either in modifying the coast-lines of the Mediterranean, or in creating any interchange of marine species; but it is likely enough to be one of a series, and we cannot predict what may be their effects. The diversion of the Nile may prove a serious matter, and now the Darien scheme has revived, a great impetus has been given to speculation, so that an ingenious projector has actually sketched a canal which should unite the Bristol Channel with the English Channel. Two more illustrations may suffice to make my meaning clear. There seems little apparent connection between woods and national greatness, but, nevertheless, the relation is a real one. When Spain lost the empire of the seas, she lost it from two causes-impoverished finances, due to a speculative trade in precious metals, and want of woods to build her ships. Her people had a foolish prejudice against trees, and an arid climate and reduced shipbuilding were the results. From Danzig to Pillau once stretched a thick pine forest. When King Frederic William I. was in want of money, one Herr Von Korff recommended its destruction. The experiment was a financial success, but the State was injured by it. As Willibald Alexis states, "the sea-winds rushed over the bared hills; the Frische Haff is half choked with sand; the channel between Elbing, the sea, and Königsberg is endangered; and the fisheries in the Haff injured. The operation of Herr Von Korff brought the King 200,000 thalers. The State would now willingly expend millions to restore the forests again."

Neither directly nor indirectly, in fact, can we touch nature by our laws, without beginning a new chain of causes, the end of which we cannot foresee. The consequences of human volition are always a little wo nderful. When the treasures of Thorwaldsen were packed up in Rome, it was not dreamed that new plants would be conveyed to Copenhagen in the grasses of the Campagna, any more than Clusius, the first European writer who mentions the potato, could possibly foresee that half the miseries of Ireland would spring from its exclusive cultivation. What we owe to our game-laws, again, is a boundless subject which might be investigated by a naturalist with profit.

My immediate purpose, however, is--strange as it may seem-with Mr. Lowe and his Budget. He deserves to be styled a real friend to the farmer, though apparently he has only given him a restricted use of germinating barley. Readers of Darwin will remember how he traces the connection between the number of cats in a given locality, and the number of humble bees, and the abundance of red clover and heartsease. Well, Mr. Lowe's Budget starts a similar House-that-Jackbuilt. The freedom of firearms from taxation affects their number in any district, the number of guns determines the number of our small birds, and the number of our small birds affects the immunity of our fields from grasshoppers, cricket-moles, beetles, locusts, slugs, \&c. Mr. Lowe was concerned for the security of life, for the prevention of early quasi-poaching habits, but his $\mathrm{I} l$. tax may effect a revolution all the same. It is no longer a secret, that wherever a persistent warfare is carried on against small birds-against martins, blackbirds, sparrows, larks, \&c.-vegetable life is sure to suffer. In the Isle of Bourbon, as M. Michelet tells us, the martin was exterminated, and a plague of grasshoppers followed; in Hungary, the sparrow was proscribed, until this valiant militia of the fields had to be recalled; in the neighbourhood 